\title{
NTNG1 wt Allele
}

National Cancer Institute

\section{Source}

National Cancer Institute. NTNG1 wt Allele. NCI Thesaurus. Code C102456.

Human NTNG1 wild-type allele is located in the vicinity of $1 \mathrm{p} 13.3$ and is approximately $343 \mathrm{~kb}$ in length. This allele, which encodes netrin-G1 protein, plays a role in neurite outgrowth. 